\title{
質問紙を用いた食塩摂取量推定について
}

高木 廣文* 金子俊** 佐伯圭一郎** 西山 悦子*3

平野 真澄*3 道場 信孝*4 日野原重明*5

\section{Estimation of Daily Salt Intake by Means of Questionnaire}

\author{
Hirofumi TAKAGI*, Shun KANEKO**, Keiichirou SAIKI**, \\ Etsuko NISHIYAMA*3, Masumi HIRANO*3, Nobutaka DOUBA*4 \\ and Shigeaki HINOHARA*5
}

To elucidate the relationship between estimate of dairy salt intake and urinary salt excretion, and to develop a questionnaire for the estimation of dairy $\mathrm{NaCl}$ intake, we conducted area surveys on 62 females living in an agricultural district and 50 females living in a fishery district.

Collected data were about all the food intakes in three days, all the urine through 24 hours, and life habits questionnaire.

The correlation coefficient were 0.393 with highly statistical significance between urinary $\mathrm{NaCl}$ excretion and computed $\mathrm{NaCl}$ intake by food survey, while the salt scale of the life habits questionnaire was found to be higher correlated, 0.410 , with the $\mathrm{NaCl}$ excretion.

Moreover, by means of Quantification Theory I to obtain the most appropriate weights for categories of items of the salt scale, multiple correlation coefficient of the salt scale with urinary $\mathrm{NaCl}$ excretion became to be 0.504 with high significance.

Finally, it was strongly suggested that the use of questionnaire must be a powerful tool to estimate the dairy salt intake in epidemiologic studies as well as food survey.

Key words : salt intake, epidemiology, life habits, urinary salt excretion, quantification theories

食塩摂取量, 疫学, 生活習慣, 食塩排泄量, 数量化理論

* 文部省統計数理研究所, ${ }^{* *}$ 文教大学教育学部

*3 (財) ライフプランニングセンター, ${ }^{* 4}$ 帝京大学医学部第 3 内科

*5 聖路加看護大学

* The Institute of Statistical Mathematics

** Faculty of Education, Bunkyo University

*3 The Life Planning Center

*4 Third Department of Internal Medicine, Teikyo University School of Medicine

*5 St. Luke's College of Nursing 


\section{I はじめに}

いわゆる成人病である悪性新生物や心疾患など は，長年のさまざまな生活習慣の影響により，発 症に至るものと考えられている. 生活習慣のらち でも食習慣は, 一般に循環器系の疾患や消化器系 の悪性新生物の発生に影響するものと考えられて いる(Doll and Peto, 1981, 青木, 大野訳, 1991). とくに食塩摄取と循環器系疾患の関係について は, 従来より多くの報告がある(小沢, 1968 ; 佐々 木，1968，1971；柳川，1976)。しかし実際には， 食塩摄取量を正確に測定するのは，それはど容易 ではない, 通常は, 陰膳法や科量法による食事調 査から推定することが考えられる。また一方では, 24時間蓄尿による食塩排泄量は, 食塩摂取量の指 標として優れたものと考えられている.

実際の地域調査や特定の疾患との関係を調べる ための疫学調査では, 多数の対象者を扱らため, できるだけ簡便で安価な方法が望ましい.さらに, 調査対象者の協力が得られ易いような，負担の少 ない調查方法が好ましい，24時間蓄尿による食塩 排泄量の測定や，陰膳法，科量法による食事調査 は被調査者に多大な負担をかけるので，この点か らはそれほと優れた方法とはいえなくなる。簡便 さとある程度の正確さを備えた方法として，分割 尿を利用する方法が考えられる（金子，1983；柴 田, 1983 ；平田, 1984 ；川崎, 1986 ; 伊藤, 1989 ； 米山， 1990 ; 田口，1991）が，分割尿を採取する 最適な時間帯について，現状として統一的な見解 が認められているとはいえない。

被調査者に負担が少なく、簡単な方法としては, 質問紙による頻度調査のような方式が考えられ る.しかし，食塩摄取量のよい推定値である24時 間蓄尿による食塩排泄量と，適当な質問紙による 食塩摂取量の推定値との関係について，一般地域 住民を対象とした報告例はほとんどみられない。

我々は, 特定地域に存在する婦人を対象として, 科量法による食事調查，24時間蓄尿による食塩排 泄量の測定，質問紙を用いた生活習慣調査などを 実施した。本研究では，これらの調查資料を用い
て, 尿中食塩排泄量を一日の食塩摄取量の測定値 として, 食事調查と質問紙調査から算出した推定 食塩摂取量の比較を行い，さらに特定時点での食 塩摂取量の推定に関して，質問紙による調査法の 有用性を検討することを目的とする。

\section{II 対象および方法}

調査対象地域としては，図１に示したように，

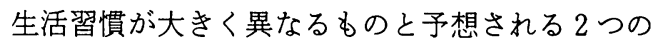
地域を選んだ。すなわち, 長野県中野市北部地域 （科野・倭地区）と千葉県安房郡白浜町である。中 野市の科野・倭地区は, 農村地帯であり, 世帯数 は約 1,000 戸，総人口は約 4,300 人である。また， 白浜町は農業・漁業関連産業を主とし, 世帯数約 2,300 戸，総人口約 7,300 人である.

調査対象者として，40～64歳の婦人を各地域 50 名ずつにする予定とし, 中野市では市の保健衛生 課を通じて調査対象者の選定を依頼し, 白浜町で は地元の医師の協力を得て調査対象者を選定し た.この結果, 中野市 62 名, 白浜町 50 名が対象と なった。な抏，中野での調査対象数が多いのは， 脱落者を見込んでいたのが, 当初の予想より調査 拒否者が少なかったためである。図 2 に示したよ

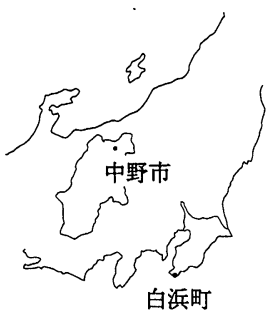

図 1 調査対象地域

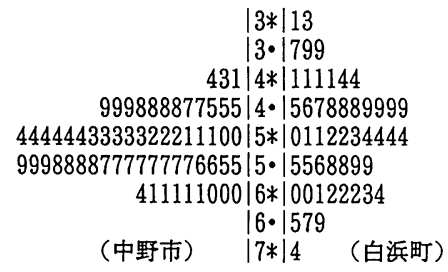

図 2 地域別調査対象者の年齢分布 
らに，中野市での年齢分布は $41 \sim 64$ 歳となり，白 浜町では31〜74歳と両側に裾野は広がったが，平 均年齢は中野市 53.7 歳, 白浜町 52.1 歳で有意差は なく，全体では53.0歳であった。

調査内容は, 質問紙による生活習慣検査（日野 原, 1982；佐伯, $1988 ；$ Takagi, 1991), 国民栄養 調査方式に準ずる科量法による 3 日間連続の食事 調査, 食塩排泄量を測定するための 24 時間蓄尿な どであった。なお, 生活習慣検査票は個人の年齢, 職業などの基本的なプロフィールについての部分 と, 生活習慣23尺度195項目からなるもので，1尺 度は基本として 8 項目からなり, 各項目の回答に 応じて $0 ， 1 ， 2$ の得点を与光，その合計を尺度 得点として用いる。 尺度によっては 9 項目から成 るものもあり，また使用されないダミ一の項目も ある。詳しくは佐伯（1988），もしくは Takagi （1991）を参照されたい.

調査期間は, 中野市は1990年 6 月 25 日 29日, 白浜町は同年 7 月 2 日 6 日と連続する各 5 日間 とした。調査初日は対象者への説明会を行い, 生 活習慣調查票を配布した。第 2 日〜 4 日に食事調 查, 第 4 日早朝 5 日早朝に 24 時間蓄尿，第 5 日 に全ての調査資料を回収した。な挆調査結果は, 各人に後日フィードバックした。なお，24時間蓄 尿の実施にあたり，採尿を忘れた場合などは，そ の旨調査用紙に記入してもららように依頼した。 この結果, 各地域 1 名ずつ, 計 2 名が蓄尿が不備 となり，分析から除外された。

本報告では, 生活習慣検査のうち主に「高塩分 尺度」に関する項目, 食事調査による食塩摂取量 の推定値，および24時間蓄尿による食塩排泄量に ついてのデータを中心に分析を行った.

なお，食塩排泄量は尿中のナトリウムイオン濃 度を電極式自動分析装置 (A\&T 社製, EA-03) に より測定し，ナトリウムと塩素が 1 対 1 で結びつ いているものと仮定して算出した。

食事調査の結果は, 四訂日本食品標準成分表(香 川綾監修，1983）に基づいてコード化され，23食 品群別 (表 2 参照) の摄取量, 食塩摂取量 (以後, 「算出食塩摂取量」と呼ぶ）などを計算した。
24時間蓄尿による食塩排泄量と食事調査による 算出食塩摄取量, および生活習慣検查の高塩分尺 度との関係の分析には, 単相関係数を求め, 無相 関の検定を行った。ささらに，高塩分尺度はカテゴ リカルデータから得点を求めているので, 高塩分 尺度項目を説明変数とし，食塩排泄量を基準変数 とした数量化理論 I 類により予測を行った(駒澤, 橋口，1988）。なお，各項目内でのカテゴリへの回 答の差による食塩排泄量の差を検討するために, 一元配置分散分析を行った.

解析には統計学パッケージ HALBAUを用い た（高木ら， 1989）.

\section{III 結果}

1. 食塩排泄量と食事調査による算出食塩摂取 量

表 1 食塩排泄量と食事調査による算出食塩摂取 量との単相関保数

\begin{tabular}{|c|c|c|}
\hline 食事区分 & 単 相 関 & 有意確率 \\
\hline 1）朝 食* & 0.255 & 0.007 \\
\hline 2）昼 & 0.358 & 0.000 \\
\hline 3）夕 食* & 0.252 & 0.007 \\
\hline 4) 間 食 & 0.139 & 0.148 \\
\hline 全 体* & 0.393 & 0.000 \\
\hline
\end{tabular}

食塩排泄量は中野市 61 名, 白浜町 49 名, 計 110 名.

*単相関が $5 \%$ 水準で有意.

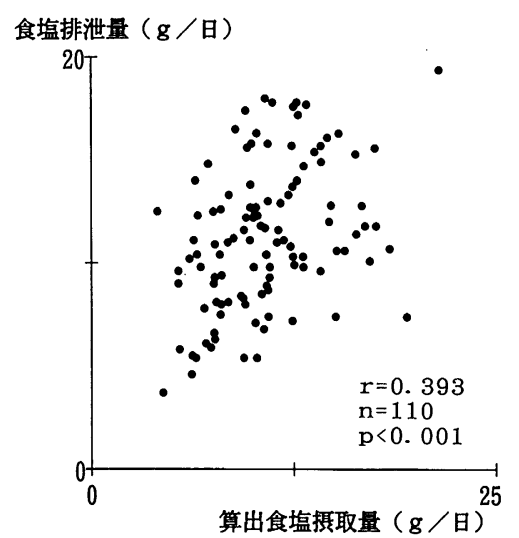

図 3 食塩排泄量と算出食塩摄取量 
表 2 食塩排泄量と食事区分別食品群摂取量との単相関係数

\begin{tabular}{|c|c|c|c|c|c|}
\hline 食 品 名 & 朝 食 & 昼 食 & 食 & 間 食 & 全 \\
\hline 1) 米 & -0.069 & 0.066 & -0.021 & -0.005 & -0.010 \\
\hline 2) ハン & 0.052 & -0.107 & -0.133 & 0.117 & 0.021 \\
\hline 3）めん類 & -0.106 & 0.049 & 0.114 & -0.082 & 0.092 \\
\hline 4) いも類 & 0.103 & 0.085 & 0.039 & -0.008 & 0.095 \\
\hline 5）砂糖 & $-0.250^{* *}$ & 0.105 & 0.027 & -0.011 & -0.041 \\
\hline 6) 菓子類 & -0.042 & -0.114 & 0.018 & $0.210^{*}$ & 0.145 \\
\hline 7）油脂 & 0.085 & 0.031 & 0.033 & 0.131 & 0.086 \\
\hline 8）味噌 & 0.091 & 0.142 & 0.118 & 0.120 & $0.192^{*}$ \\
\hline 9）豆・豆製品 & -0.038 & 0.022 & -0.027 & -0.051 & -0.026 \\
\hline 10）その他豆類 & -0.032 & -0.086 & -0.029 & 0.068 & -0.022 \\
\hline 11）果実類 & -0.073 & 0.010 & -0.031 & 0.039 & -0.002 \\
\hline 12）緑黄色野菜 & -0.136 & 0.032 & -0.043 & 0.111 & -0.047 \\
\hline 13）淡色野菜 & $0.237^{*}$ & $0.302^{* *}$ & $0.239^{*}$ & 0.118 & $0.341^{* *}$ \\
\hline 14）海藻類 & -0.024 & -0.120 & -0.179 & 0.006 & -0.148 \\
\hline 15）調味料 & -0.021 & 0.151 & 0.185 & -0.082 & 0.166 \\
\hline 16）酒類 & $-0.201^{*}$ & -0.067 & 0.062 & 0.177 & 0.088 \\
\hline 17）㫮好飲料 & 0.105 & -0.146 & -0.042 & $0.288^{* *}$ & $0.221^{*}$ \\
\hline 18）魚介類 & $0.252^{* *}$ & 0.005 & -0.027 & -0.040 & 0.071 \\
\hline 19）肉類 & 0.065 & 0.005 & 0.142 & 0.049 & 0.125 \\
\hline 20）卵 & -0.106 & 0.087 & $0.207^{*}$ & 0.157 & 0.095 \\
\hline 21）乳 & 0.155 & 0.008 & 0.048 & -0.045 & 0.076 \\
\hline 22）乳製品 & 0.105 & -0.030 & 0.059 & 0.037 & 0.079 \\
\hline 23）加工食品 & -0.047 & 0.120 & 0.001 & 0.000 & 0.050 \\
\hline
\end{tabular}

注）食塩排泄量は中野市61名, 白浜町49名, 計110名. ${ }^{*} \mathrm{p}<0.05, \quad{ }^{* *} \mathrm{p}<0.01$

表 1 に24時間蓄尿による食塩排泄量と, 食事調 査 (秤量法) による算出食塩摄取量の単相関係数 とその検定結果の有意確率を食事区分ごとに示し た。 また，図 3 には食塩排泄量と算出食塩摂取量 の相関図を示した，相関図からは正の相関はある が,それほど直線関係は大きくないことがわかる。 表 1 から，食事区分による算出食塩摄取量は間食 を除いて, 食塩排泄量と有意な相関を示している。 最も高い相関は昼食の算出食塩摂取量であり， 0.358 単相関であった。しかし, 食事区分別より も, 合算して求めた 1 日あたりの算出食塩摄取量 の方が 0.393 とよ大さな単相関係数を示した。

表 2 は食事区分別に23食品群の摂取量と食塩排 泄量の単相関係数を調べたものである，全体とし ては, 淡色野菜 0.341 , 嗜好飲料 0.221 , 味噌 0.192 と食塩排泄量と 3 食品群が有意な相関を示した。 食事区分別にみると，淡色野菜では間食を除いて 全て有意な相関を示したが，嗜好领料では間食の
み有意であり，味噌では全て有意ではなかった。 その他の食品群での単相関係数は, 朝食の砂糖 -0.250 , 酒類 -0.201 , 魚介類 0.252 , 夕食の卵 0.207 , 間食の菓子類 0.210 などが食塩排泄量と有 意な相関を示した。

\section{2. 食塩排泄量と生活習慣尺度}

表 3 に生活習慣尺度得点と食塩排泄量の単相関 係数とその無相関の検定結果の有意確率を示し た。尿中食塩排泄量と有意な相関を示したのは高 塩分, 糖分, 肉・油脂, 扣よび喫煙の 4 尺度であっ た. とくに, 高塩分尺度と食塩排泄量の単相関係 数は 0.410 と, 食事調査による算出食塩摄取量の 0.393 といら值よりも大きかった。なお，母相関係 数の $95 \%$ 信頼区間を求めると, 食塩排泄量と高塩 分尺度は $(0.241,0.555)$ となり，算出食塩摂取 量とは $(0.222,0.540)$ となる。

図 4 は高塩分尺度と食塩排泄量の相関図であ る. 生活習慣尺度は, 特定の 8 項目について $3 つ$ 
表 3 食塩排泄量と生活習慣尺度との単相関係数

\begin{tabular}{lrc}
\hline \multicolumn{1}{c}{ 変 数 名 } & 単 相 関 & 有意確率 \\
\hline 高塩分* & 0.410 & 0.000 \\
糖分* & 0.281 & 0.002 \\
肉一油脂* & 0.259 & 0.006 \\
偰煙* & 0.194 & 0.041 \\
飲酒 & 0.159 & 0.096 \\
洋風の食事 & 0.140 & 0.144 \\
食事の規則性 & -0.095 & 0.321 \\
料理への進取性 & -0.069 & 0.475 \\
経済型 & 0.145 & 0.129 \\
共感性 & 0.132 & 0.167 \\
教養 & -0.131 & 0.172 \\
清潔 & -0.129 & 0.178 \\
外向性 & 0.125 & 0.194 \\
妻主導型 & 0.115 & 0.230 \\
自発性 & 0.093 & 0.334 \\
疾病頻度 & -0.080 & 0.407 \\
俁楽 & 0.062 & 0.517 \\
運動の実施 & 0.058 & 0.550 \\
社会奉仕 & -0.056 & 0.561 \\
義理人情 & 0.054 & 0.578 \\
保守中庸 & -0.042 & 0.663 \\
情緒不安定 & -0.019 & 0.841 \\
健康観 & 0.016 & 0.866 \\
多愁訴 & -0.004 & 0.968 \\
\hline 注) & & \\
\hline
\end{tabular}

注）食塩排泄量は中野市61名, 白浜町 49 名, 計 110 名。

*単相関が $5 \%$ 水準で有意.

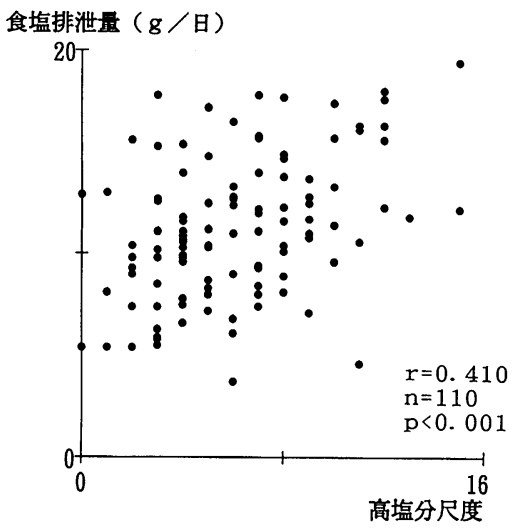

図 4 食塩排泄量と高塩分尺度

のカテゴリから 1 つを回答として選択させ，カテ ゴリに応じて $0 ， 1 ， 2$ の得点を与えている. 従っ て，図4のように高塩分尺度得点は 0 から16点屯
表 4 高塩分尺度項目と尿中食塩排泄量との単相 関係数

\begin{tabular}{|c|c|c|c|}
\hline & 尺度 項 目 名 & 単 相 関 & 有意確率 \\
\hline Q17 & $\begin{array}{l}\text { おかかずに醬油, ソース, 塩 } \\
\text { などをか話る }\end{array}$ & 0.239 & 0.012 \\
\hline Q40 & ひものや塩ざけを食べる & 0.294 & 0.002 \\
\hline Q63 & 漬けものを食べる & 0.299 & 0.002 \\
\hline Q86 & $\begin{array}{l}\text { 漬けものにはしょう油を } \\
\text { がる }\end{array}$ & 0.228 & 0.017 \\
\hline Q109 & $\begin{array}{l}\text { 食塩をとりすぎないよう } \\
\text { に爻をつる }\end{array}$ & 0.274 & 0.004 \\
\hline Q132 & $\begin{array}{l}\text { おかずは味付けの濃いも } \\
\text { のを食べる }\end{array}$ & 0.222 & 0.020 \\
\hline Q155 & $\begin{array}{l}\text { 漬けものにはしょら油と } \\
\text { 味の素の両方をかける }\end{array}$ & 0.249 & 0.009 \\
\hline Q188 & みそ汁を飲む & 0.193 & 0.043 \\
\hline
\end{tabular}

注）食塩排泄量は中野市 61 名, 白浜町 49 名, 計 110 名. 番号は生活習慣検査票での項目番号.

での17種の離散的な值しかとらない。

高塩分尺度に含まれる 8 項目について, 表 4 に 食塩排泄量との単相関係数と無相関の検定結果の 有意確率を示したが，5\%以下の水準で全項目が 統計学的に有意であった。な䪱目番号 Q109は, 減塩の意識に関する項目であり, 得点は他の項目 の逆順に与えられている.したがって, 減塩の意識 が高いほど食塩排泄量が少ないことを示している。

ところで, 前述のように, 各項目は $0,1 ， 2$ の わずか 3 種類の数値しか取らないので,そのまま 単相関を計算するよりも, 各項目のカテゴリ別の 食塩排泄量の平均値を比較すべきかも知れない.

表 5 は, 高塩分尺度項目のカテゴリ別に尿中食 塩排泄量の平均値を分散分析により検討したもの である．全ての項目で質問に肯定的な回答ほど， 食塩排泄量の平均值が大きくなっていることが分 かる（Q109では，逆に値が小さくなる). しかし， Q86, Q132, および Q188の 3 項目は, 無相関の検 定結果とは異なり，5\%水準で有意差が認められ なかった。

高塩分尺度得点と尿中食塩排泄量との間に相関 が認められたが，すでに述べたように，高塩分尺 度は離散的なアイテムーカテゴリからなるので, 数 量化理論 I 類の方が妥当な方法かもしれない（駒 澤，橋口，1988）。 
表 5 高塩分尺度項目の各カテゴリ別食塩排泄量の平均值と標準偏差 (SD)

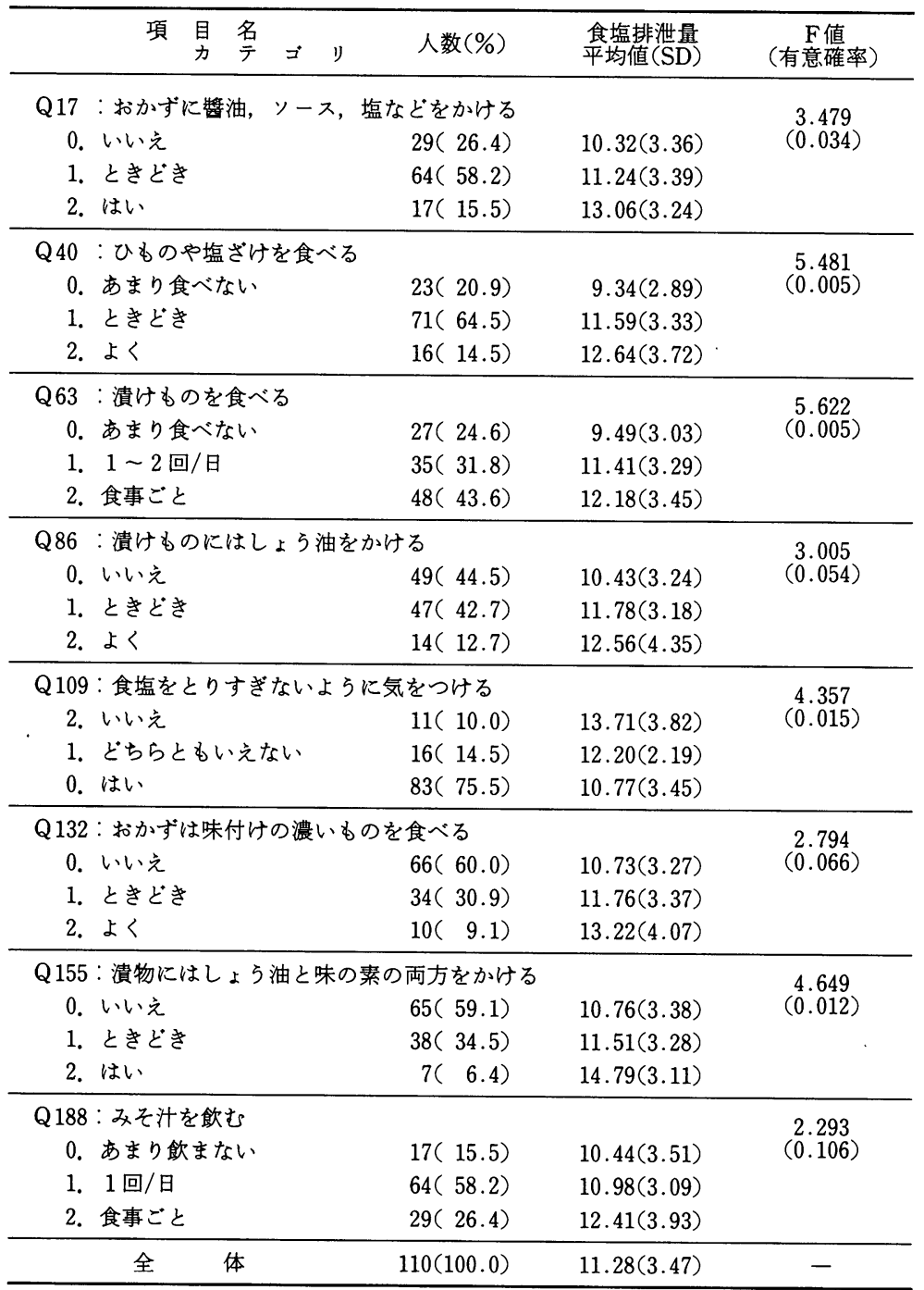

（注）各カテコリの番号は, 尺度得点を計算する場合に与える数値.

表 6 に食塩排泄量を基準変数に, 高塩分尺度項 目を説明変数とした数量化理論 I 類による各項目 のカテゴリへの数量（重み）と重相関係数を示し た。高塩分尺度得点を計算する場合には， $0 ， 1$ ， 2 の得点を各項目のカテゴリに与えているが，カ テゴリ数量がその順序と同じであった項目は, Q17, Q40, Q63, Q109(他の項目とは逆順)，Q132 の 5 項目であったＱQ86では中間のカテゴリに, Q155とQ188では両側のカテゴリの数量が大きく
なっていた。偏相関係数の最も大きかった項目は Q40（ひものや塩ざけを食べる）であり，次に Q63（漬けものを食べる）であった.

図 5 に食塩排泄量と数量化理論 I 類による推定 量との相関図を示した. 両者の重相関係数は0.504 となり, 単に $0,1 ， 2$ の得点から計算した高塩 分尺度得点を用いる場合の 0.410 よりも大きく, 食 事調査からの算出食塩摄取量による0.393よりも 大きかった。 
表 6 食塩排泄量の予測のための高塩分尺度項目 カテゴリの数量（数量化理論 I 類による）

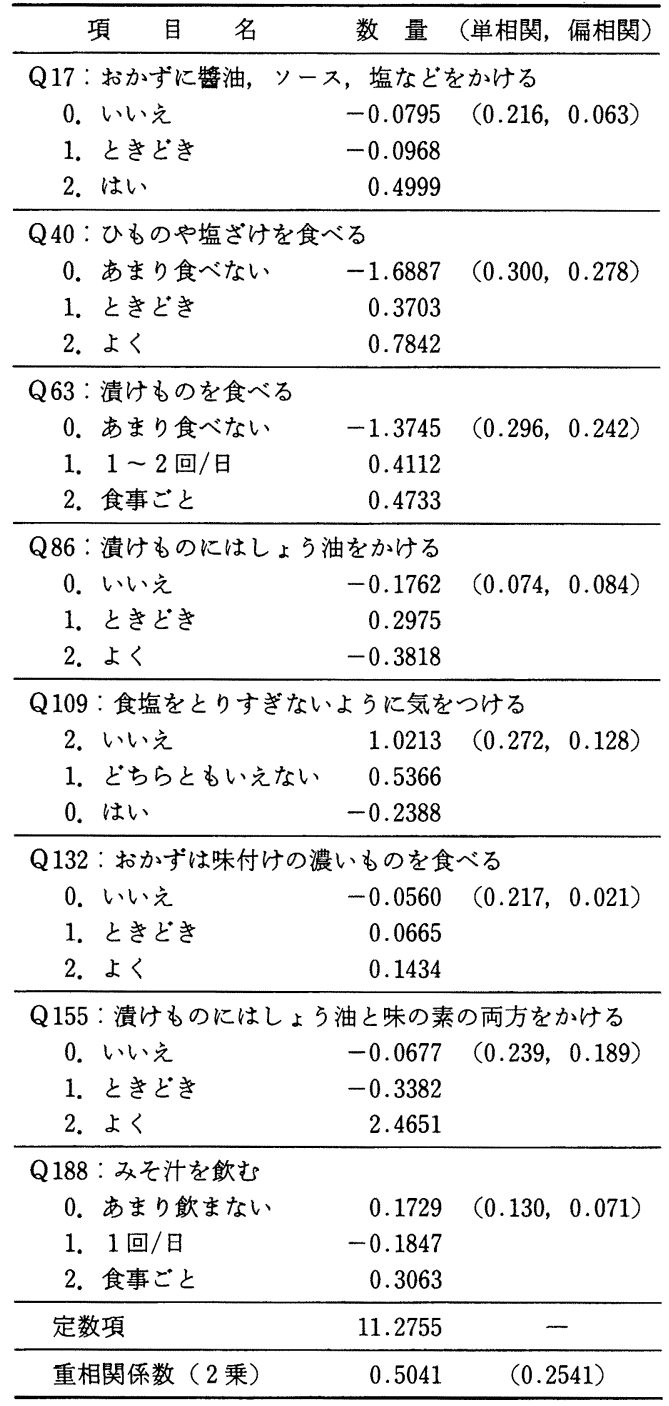

注）各カテゴリの番号は，尺度得点を計算する場合に 与える数値. 単相関, 偏相関は数量化後の項目之食塩排 泄量の値.

\section{IV 考察}

ここでは, 本研究で得られた主要な結果につい て考察を加えるが，まず本研究の調査に関する問 題点を指摘し, その後, 食塩摂取量の推定のため の簡便な方法に関して，考察を行うことにする.

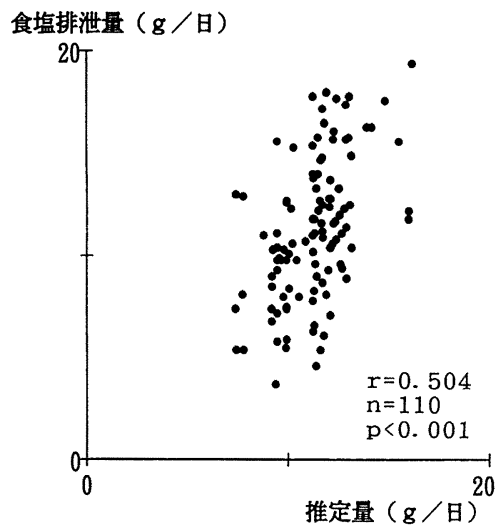

図 5 食塩排泄量と推定量

\section{24時間蓄尿調査の正確さについて}

本研究では, 調査対象者全員が24時間蓄尿を正 しく行ったものとして，すべての解析を行ってい る、今回の調査で同時に実施した秤量法による食 事調査では，3 日間毎日一度は（管理）栄養士が 対象者を訪問するか，所定の場所で調査用紙への 記入の確認や質問などに応じた，従って，食事調 査に関しては比較的信頼できるデータが収集され たものと考えて良いだろう。また，生活習慣調査 については，説明会で記載方法などについては， 丁寧に指示を与えた。しかし，高齢者も調查対象 者には含まれているので，必ずしも説明会だけで は十分でなかったかも知れない，実際には，調査 者は食事調査のために，必ず被調査者と毎日面接 を行ったので, 生活習慣調查票の回答の仕方なぞ について, 不明な点や記載についての確認などは, その場を利用して行った。

今回は測定していないが，尿中クレアチニン排 泄量を蓄尿の正確さの指標として用いることも考 えられるが(川崎，1984），実際の調査では個人に ついて24時間蓄尿を一度実施できればよい方であ ろ5。従って，本調査のような場合には，尿中ク レアチニンの個体内変動については言及できな い。をた，伊藤（1989）が指摘したように，尿中 クレアチニンの個人内での変動はそれほど小さく ない. 本研究では, クレアチニンの測定を行って いないので，調査の信頼性について，この点から 
の言及はできない、ただし，調査への対象者の態 度は概ね好意的であり，極めて協力的であった。 “実際, 本調査対象地域である長野県中野市では, 保健衛生課を中心に, 約十年前から 24 時間蓄尿に よる食塩排泄量の調査を毎年千人以上の規模で実 施している。また白浜町の対象者も多くの者が前 年までに 24 時間蓄尿の経験者であり, 調查の方法 をよく理解していた，この点からいえば，収集し たデータは信頼に足るものであると，我々は考え ている.ただし，24時間蓄尿などのデータの信頼性 については, 今後の課題として重要なものであり, 客観的で簡便で適切な判定方法が必要とされる。

2. 食塩排泄量への発汗の影響について 24 時間蓄尿調査の調査対象時期が 6 月， 7 月と いう点から, 暑さに伴う発汗による食塩の排泄の 問題がある。しかし，本調査期間中は梅雨があけ て扔らず，そのため気温はそれほど高くならな かった。したがって，発汗に伴う尿中食塩の減少 は，結果に重大な影響を及ぼすほど大きくなかっ たものと考兄られる。実際, 食塩排泄量の平均值 は11.3g/日であり，秤量法による食事調査から推 定される平均値 $10.8 \mathrm{~g} /$ 日よりも大きかった。この 点からも, 発汗による尿中食塩の減少の問題は, 本研究では小さいものと思われるが，発汗につい て正確な観察・測定を行っていないので，今後の 研究においては吟味すべき課題である。

3. 食事調查と尿中食塩排泄量

特定時点, 通常はある 1 日の食塩排泄量の推定 の方法として, 食事調查に基づくデータから計算 するのが一般的であろう。とくに，陰膳法は被調 査者が飲食したものと同一, 同量の食品を入手し て分析を行らので, 最も信頼性の高い值が得られ る。しかし，対象者は調査期間中は常に 2 人分の 食事を用意する必要がある。このため，比較的多 人数を対象とした疫学調查での実施は, 対象者に かかる負担と必要とされる経費の面から，ほとん ど不可能といえよう。

24時間蓄尿による食塩排泄量の測定は, 陰膳法 に比べれば，実施可能な方法といえる，この方法 が妥当性をもつのは, 食塩排泄量は食塩摄取量の
值と平行するものと考えられるからである.実際, 田口ら (1991) は $\mathrm{Na}$ 摄取量と尿中 $\mathrm{Na}$ 排泄量につ いて最大で $0.910 の$ 単相関係数を報告している.た だし，実施に损いては被調查者にかかる負担は大 きい，とくに，自宅外で職業に従事している対象 者は，通勤の交通機関や職場内にビニールパック などの採尿用の容器を持ち込まねばならず, 精神 的に恥ずかしさや，面倒くささを感じる人は少な くないだろう。

この点からも, 疫学調査のように多数の対象者 を扱らためには，可能な限り簡単に実施できる調 査方法が，開発されることが望まれよう。

一日の分割尿を用いる方法は，簡便に㬰施可能 であり，優れた方法と考えられるが，実施時間に ついて統一的な見解がまだ認められない（金子， 1983 ; 柴田, 1983 ; 平田, 1984 ; 川崎, 1986 ; 伊 藤， $1989 ＼mathrm{~ ， 米 山 ， 1990 ； 田 口 ， 1991 ） 。 こ の 点 に つ ~}$ いて, 妥当な結論が得られれば, 疫学調査で有用 なものとなろう.

一方，秤量法は摂取した食品名と重量から，そ れに対応する食品成分表に記載された数値をか け，全食品について合計を求めることによって， 食塩摄取量などの必要とされる栄養素が計算され る，当然のことではあるが，食品成分表に揭載の 数值と実際に摂取した食品に含まれている各種の 栄養素の量は一致するとは限らない，どの程度の 正確さが要求されるかは, 研究の目的にも依存す るが，エネルギ一，糖分，脂肪，蛋白などの摂取 量は比較的数值が大きいこともあり，若干の誤差 は許容できるのではないかと考兄られよう。しか し，食塩のように摂取量がそれほど大きくない栄 養素については，相対的に大きな誤差が入り込む 可能性は，秤量法では大きくなると考兄られる。

結果ですでに述べたよらに，食事調査から得ら れた算出食塩摄取量と尿中食塩排泄量の単相関係 数は 0.393 と, 有意であるが, それほど大きな值と はいえないものであった。この理由の一つとして， 食事調査による算出食塩摄取量は 3 日間の平均値 であるが，食塩排泄量は特定日の 1 日量であり， 測定日は必ずしも一致して扣らず，そのため相関 
は低めになると考兄られる，しかし，実際の個人 の食塩㩒取量の日間変動が大きくなく，一定の值 を保っているのであれば，比較的高度な相関が認 められてしかるべきであろう。

ところで，伊藤（1989）によれば，陰膳法と科 量法による $\mathrm{Na}$ 摂取量の単相関は $0.578(\mathrm{p}<0.01$, $\mathrm{n}=27)$ と比較的高い相関を示している.我々の調 查では，陰膳による食事調査を実施していないの で，この点については言及できない，しかし，科 量法による食事調査の負担は, 陰膳法や24時間蓄 尿と比べて優るとも劣らないものであろう，両者 の相関係数がかかる労力に見合って，十分に大き いとは考えがたい。

食事調査は単に食塩摂取量を推定するために行 うのではないので，秤量法による食事調査を否定 するものでもない，しかし，被調査者への負担と 調查者の経費・負担を考えた場合，それはど効率 のよい調査方法とはいえないことは確かである。

4. 質問紙による食塩摂取量の推定

結果で述べたように，生活習慣検査に含まれて いる高塩分尺度得点と, 尿中食塩排泄量との単相 関係数は 0.410 あ, 食事調査 (秤量法) に上る算 出食塩摄取量の 0.393 と比べて, 統計学的な有意差 はないものの，より大きな数值を示した。

実際の調查を実施する場合，かかる労力の大き さからいえば，質問紙を用いる方法は，その簡便 さと低廉さから，魅力的な調查方式といえるだろ う. 生活習慣検査票の回答に要する時間は，せい ぜい30分程度であり, わずか 8 項目しかない高塩 分尺度項目のみならば，数分程度の時間しか要し ないだろう。秤量法による食事調査が（管理）栄 養士などの有能な専門家を多数必要とすることを

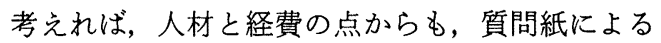
方法は優れたものといえる。

さらに，尿中塩分排泄量と高塩分尺度項目に関 するデータへの数量化理論 I 類の適用の結果で は，重相関係数が 0.504 とわずかながら上昇した。 質問項目の内容を若干变更したり, 項目数を増 やすことなどで, 食塩排泄量とょり相関の高い尺 度が構成されるものと考劣られる。実際の食塩摂
取量と相関が高く，より信頼性の高い質問項目の 設定に関しては, 今後の研究課題として重要であ り, 疫学調查での応用などの面からも継続的に検 討する必要があると考えられる。

24時間蓄尿により測定された食塩排泄量は，食 塩摂取量の極めてよい推定量と考えられるので, このことは，長期の食習慣を測るために設定され た高塩分尺度項目を用いることで，特定時点での 食塩摂取量をある程度は推定できることを示すも のと考えられよう。

一般に，質問紙による生活習慣調查の目的は， 長期に亘る個人のある特性の傾向を測ることであ ろう。ここで使用した高塩分尺度に関しても，元 来は長期的な塩分摂取の傾向性を把握するために 開発されたものである。したがって，高塩分尺度 得点が特定の 1 日の尿中食塩排泄量と, 必ずしも 高い相関を持つ必要はないかもしれない。しかし ながら, 本研究では両者に高度な相関が認められ た。この理由は必ずしも明らかではないが，個人 の食塩摄取量は変動するものの, 比較的せをい範 囲におさまるためではないかと考えられる，個人 の食塩摄取量が比較的安定したものであれば, 前 述したように秤量法による算出食塩摄取量と尿中 食塩排泄量に相関が認められるはずであるし，質 問紙による高塩分尺度得点とも相関が認められる ことになる。

個人の食物摄取の傾向は, 長期的には大きく変 化するかもしれないが，特定の疾患への罹患等が なく，医師や栄養士などから食事指導などを受け ていないのであれば，短期間にはそれほど変化す るものではないと考えられょう，とくに，短期間 に味の好みが大きく变わるとは考劣にくい，しか しながら，一般地域住民を対象として長期に亘り 食塩摄取量を陰膳法などで，正確に調査した報告 はないので, 食塩摂取量などの個体内変動に関し ては，今後の研究が待たれる。

\section{V 結 論}

農業地域在住の婦人 62 名と漁業地域在住の婦人 50 名について, 生活習慣調查, 食事調查, および 
24時間蓄尿による食塩排泄調査を実施し, 尿中食 塩排泄量を中心にデータ解析を行い, 簡便な食塩 摂取量推定のための調査方法について検討した。 その結果，以下のことが明らかとなった。

1. 食事調査による算出食塩摄取量と尿中食塩 排泄量の単相関係数は0.393であった。

2. 生活習慣検査の高塩分尺度得点と㽷中食塩 排泄量の単相関係数は0.410であった。

3. 高塩分尺度を構成する 8 項目と食塩排泄量 の単相関係数は絶対值で 0.193 から0.299の大ささ があった。 また，各項目の各カテゴリごとの食塩 排泄量の平均値は，カテゴリ順に大きくなる（小 さくなる）といら一定の傾向が認められた.

4. 食塩排泄量を基準変数, 高塩分尺度項目を説 明変数とした数量化理論 I 類を行ったところ, 重 相関係数は若干大きくなり，0.504となった.

5. 以上の結果に考察を加え, 日常の食塩摂取量 の推定値として, 科量法による食事調査と比べて, 質問紙による簡便な調査方法によっても, 同程度 の信頼性のある食塩摂取量の推定が行えることが 示唆された。

謝辞：調查に御協力頂いた長野県中野市科野・倭地 区ならびに千葉県安房郡白浜町の住民の方々, 中野市 保健衛生課の方々, 白浜町の和穎美和子医師, 財団法 人ライフプランニングセンターの臨床検査部の北川輝 子氏扣よび関係各位に深謝致します。なお，本研究の 一部は文部省統計数理研究所共同研究 (2-共研-71, 3-共研-72，4-共研-75)，おょび WHO Medical Research Grant (WP) MRO/ICP/HSR/001-A の援 助を得た.

\section{文献}

青木國雄, 大野良之 訳 (1991)：ガンはどれだけ避け られるか, 今日のアメリカの研究成果から, 名古屋 大学出版会 (名古屋), Doll, R. \& Peto, R. (1981): The Cause of Cancer, Quantitative Estimates of Avoidable Risks of Cancer in the United States Today, Oxford University Press Inc. (New York) 日野原重明, 柳井晴夫, 高木廣文, 柏木恵子, 日野原 緑 (1982)：循環器疾患予防のための生活習慣に関 する研究 (第 1 報) 生活習慣の多変量解析による分 析, 日本公衛誌, 29(7), 309-320
平田清文，他（1984）：朝のスポット尿による食塩摄 取の簡易測定法，医学のあゆみ，129(6), 411-416

伊藤和枝 (1989)：分割尿を用いたナトリウムならび にカリウム摂取量推定法の検討, 日本公衛誌, 36(10), $701-709$

香川 綾 監修 (1983)：四訂食品成分表, 女子栄養大 学出版部 (東京)

金子佳代子, 小池五郎 (1983)：夜間尿への食塩排泄 量から食塩摂取量を推定する方法に関する一考察, 日本栄養食糧学会, 36(1), 43-46

川崎晃一, 他 (1984): 尿中クレアチニン排泄量に関 する研究（1）-24時間排泄量に及ぼす年歯, 性, 運動执よび食塩摄取量の影響と日周変動, 健康科学, $6,1-8$

川崎晃一, 他 (1986)：24時間尿中 $\mathrm{Na}$ 排泄量推定法に 関する研究一尿中クレアチニン排泄量予測值と分割 尿を用いた推定法の基礎的検討一, 健康科学, 8,57 $-63$

駒澤 勉, 橋口捷久 (1988)：パソコン数量化分析, 朝倉書店 (東京)

佐伯圭一郎, 高木廣文, 日野原重明, 柳井晴夫, 道場 信孝, 水口 緑 (1988)： LPC 式生活習慣検査の作 成, 行動計量学, 15(2), 32-44

佐々木直亮 (1968)：循環器疾患と食物との関係, と くに高血圧と食塩恸取との関連について, 厚生の指 標, 15(2), 38-44

佐々木直亮 (1971): 疫学面よりみた食塩と高血圧, 最新医学, 26, 2270-2279

柴田 博 (1983)：食塩撰取量の推定法について, 最 新医学, 38(4), 649-653

Takagi, H., Saiki, K., Hinohara, S., Yanai, H., Douba, N. \& Mizuguchi, M. (1991): Construction of the Life Habits Inventory, Methods and Applications in Mental Health Surveys, Suzuki, S. \& Roberts, R.E., eds., $103-121$ and $297-306$, University of Tokyo Press (Tokyo)

高木廣文, 佐伯圭一郎, 中井里史(1989)：HALBAU によるデータ解析入門, 現代数学社 (京都)

田口徹也, 柳 修平, 中村健一 (1991): 食塩摂取量 別ナトリウム摂取量と尿中排泄量の関係, 民族衛生, 57(3), 97-106

小沢秀樹 (1968)：脳卒中の地域差と過去の食生活, 日本公衛誌, $15,551-566$

柳川 洋, 橋本 勉, 福富和夫, 川口 毅, 竹内和子, 重松逸造 (1976)：循環器死亡率の地域格差之食品 摄取に関する統計的検討, 23(11), 711-719

米山京子, 池田順子, 永田久紀 (1990): 尿中 $\mathrm{Na} /$ ク レアチニン, NA/Kの日内変動扎よび24時間尿中 $\mathrm{Na}, \mathrm{Na} / \mathrm{K}$ との関連, 日本公衛誌, 37(1), 45-52

（受稿 1992. 9. 21） 